\title{
The Importance of Teacher Training for Development of Gifted Students' Creativity: Contributions of Vygotsky
}

\author{
Fernanda Hellen Ribeiro Piske1, Tania Stoltz ${ }^{1}$, Ettiène Guérios ${ }^{1}$, Denise de Camargo², \\ Carla Luciane Blum Vestena ${ }^{3}$, Samarah Perszel de Freitas ${ }^{4}$, \\ Ana Aparecida de Oliveira Machado Barby ${ }^{5}$, Jamille Santinello ${ }^{5}$
}

\author{
${ }^{1}$ Federal University of Paraná, Curitiba, Brazil \\ ${ }^{2}$ Tuiuti University, Curitiba, Brazil \\ ${ }^{3}$ Unicentro/UFPR, Guarapuava, Brazil \\ ${ }^{4}$ Positivo University, Curitiba, Brazil \\ ${ }^{5}$ Unicentro, Guarapuava, Brazil \\ Email:nandahellen@hotmail.com
}

How to cite this paper: Piske, F. H. R., Stoltz, T., Guérios, E., de Camargo, D., Vestena, C. L. B., de Freitas, S. P., de Oliveira Machado Barby, A. A., \& Santinello, J. (2017). The Importance of Teacher Training for Development of Gifted Students' Creativity: Contributions of Vygotsky. Creative Education, 8, 131-141.

http://dx.doi.org/10.4236/ce.2017.81011

Received: August 22, 2016

Accepted: January 19, 2017

Published: January 22, 2017

Copyright (c) 2017 by authors and Scientific Research Publishing Inc. This work is licensed under the Creative Commons Attribution International License (CC BY 4.0).

http://creativecommons.org/licenses/by/4.0/

\begin{abstract}
The creativity is expressed in all individuals, but it manifests itself in different proportions and it may be carried out at different levels. Development levels of this attribute depend on the teacher's mediation in the process of learning. Creativity can be a challenge for most teachers, since they are unaware of its importance and unwittingly they inhibit by teaching methods that are not aimed at instigating the potential of students. Thus, this article aims to highlight the importance of teacher training for the development of gifted creativity. In conclusion, the mediation of teachers makes the difference in gifted education. As Vygotsky explains, it is precisely through the mediation that it is possible to develop the creative potential. In this sense, the training of the teaching staff reflects in how the mediation will take place during the process of teaching and learning. Therefore, it is essential that teachers are prepared to create a stimulating environment of potential and talents, as well as in performing a work with creativity of their students.
\end{abstract}

\section{Keywords}

Creativity, Teacher Training, Gifted Students, Vygotsky

\section{Introduction}

All teachers should work with a creative teaching. This paper will focus on the work of teachers of gifted students. Creativity can be worked in several ages and 
it should be developed during all classes through activities that represent challenge for students. Creativity is essential in education because without this attribute, teaching is meaningless to exist. So this attribute should be worked in all levels of the process of teaching and learning (Renzulli, 2005; Gross, 2016; Pfeiffer, 2016; Piske, 2016, Piske \& Stoltz, 2013; Piske et al. 2016).

Through creativity is possible to help gifted students have a good self-esteem and avoid some social and emotional difficulties at school. Teachers should work with curriculum enrichment ${ }^{1}$ with additional activities, i.e. activities for students to advance during learning in their area of interest.

Creativity can be defined as the quality or characteristic of who or what is creative. Create is an important act to avoid a monotonous and tiring teaching. So if we think about teaching students with high potential, creativity can be an attribute considered essential to make these students interested in learning and attending school.

Otherwise, the process of teaching and learning can lose sense. There is no reason to attend school to learn always the same things. "The relevance of creativity in daily life and in promotion of personal well-being becomes an educational goal that should have priority" (Bahia, 2016: p. 146).

In the scope of the school and the teacher education, Guérios (2002) defends that the development of the creative potential of the individuals is associated with the motivation to make it and, because of this, to learn it. If to think about the school, in turn, creative teachers in their methods of education can motivate the students to learn it. Therefore, Guérios $(2002,2005)$ defends that experiential epistemology of knowledge construction is the bedding of the didactic action where teachers are mediating between students, surrounding life and knowledge.

Many researchers indicate creativity as a fundamental aspect in the process of learning of gifted students (Renzulli \& Reis, 1997; Renzulli, 2005; Gross, 2016; Pfeiffer, 2016; Alencar, 2001, 2014; Piske \& Stoltz, 2013; Piske et al. 2015; Piske, 2016; Guérios, 2002; Guérios \& Sausen, 2013; Stoltz, 2016, among other authors).

Some definitions of creativity make us understand its importance in teaching and clarify that without this attribute the process of learning would have no reason to exist. Esparza et al. (2016, p. 44) explain that "creativity is the ability to produce something new, unique and unexpected, but also something appropriate that is adapted to the characteristics of the task".

For Lowenfeld \& Brittain (1977), creativity is related to a productive, innovative behavior and that builds on actions that enable achievements, it should basically be a contribution of the creative individual. The creation process of gifted students occurs naturally and flows when it finds a way to explore their ideas and when they can express their wishes and interests.

Alencar (1995) \& Cerna (1999) point out that creativity is expressed in all individuals, but it manifests itself in different proportions and it may be carried

${ }^{1}$ Teachers can work with Curriculum enrichment using activities that add or go beyond the existing curriculum. They may occur in the classroom or in a separate setting such as a pull-out program (Piske, 2016; Piske et al., 2016). 
out at different levels. Thus, it is possible to understand that all individuals have a creative capacity. This capacity can be improved and developed in a stimulating environment.

According to Virgolim, Fleith \& Neves-Pereira (2009) creativity seems to be in the category of attribute of the nature of each person, however, in most cases, we are not inserted in an environment that allows the expression of creativity, on the contrary, education that some education professionals offer at schools, in a general way, just hinder the creative potential.

Dealing with creativity is dealing with emotions, feelings and sensations of each person represent the essential fuel to make the creation process happen spontaneously. It is important to highlight the importance of emotional states in the development of creative individual, because when the level of satisfaction increases, hence the self-esteem becomes better and the self-concept can become positive (Piske, Stoltz, \& Machado, 2014).

For Goldberg (1986) creativity is a process that leads to a particular artistic product; it is an attitude towards yourself and other people that allows intimate relationships through desire, passion and imagination. This process must take place in a different way that many schools offer, because being creative is to express the innermost feelings.

\section{Necessity of Training for Teaching Staff to Work with Creativity}

At school, creativity is a challenge for most teachers, since they are unaware of its importance and unwittingly they inhibit by teaching methods that are not aimed at instigating the potential of students, in addition, teaching becomes monotonous and tiring (Piske, 2015, 2016; Piske et al., 2016).

Alencar (2014) explains that far from working with creativity, teachers offer a repetitive teaching during their classes and this teaching does not lead to a reflection about what students are learning. Therefore, the mediation of the teaching staff is crucial to create a stimulating environment of creativity.

What Alencar (2014) explains compels to reflect on the teachers training. Mindal and Guérios (2013, pp. 27-28) had identified that one of the points of tension in the courses of teachers training for the basic education are that the curricular models "remain prescriptive, composites for knowledge broken up in multiples discipline and a clear dichotomy between the theoretical and the practical knowledge, beyond the specific knowledge of what to teach and as to teach it. Also, it is recurrent to mention the lack of curricular proposals that make interaction between the specific and pedagogical school, knowledge, the teaching and the society". In opposition the displayed, Guérios (2002) defends a teachers training that it qualifies them to promote the development of the creativity in the students. Guérios \& Sausen (2013) believes that the creativity is associated with the motivation to learn it and the teachers, in turn, must be creative in its methods to motivate the students.

For Vygotsky (2001, 2008, 2009, 2010), mediation is the intervention process 
where an element, individual or object, can be intermediate and can act in a relationship. It is possible to explain that this relationship between the child and the environment is mediated by this intermediate element. The child learns through the intermediate element and internalizes knowledge, appropriating of a new information (Vygotsky, 2010). Mediation of the intermediate element is essential in the process of teaching and learning, it is from the action of this element that gifted students develop their high abilities and talents as well as their creativity.

Stoltz \& Piske (2012), Piske (2015, 2016) explain that mediation is determined by the use of tools and signs. When the individual interacts with his/her cultural context, he/she has access to objects and cultural tools which allow his/her activity in the environment. These tools enable the transformation of his/her reality.

So, the teacher who knows how to use appropriate tools can provide a quality education. These tools can mean efficient materials that when used appropriately makes possible an education that focus on a full development of students.

According to Kane (2016) is essential that teacher-as the main mediator of the teaching and learning process-makes a reflection about his/her teaching practice and also about his/her important role to motivate students to perform their inventions. It is important that teacher creates possibilities for innovative action and works with creativity using challenging exercises during his/her classes.

Alencar (1995) explains that what will determine whether a person has a creative potential more significant than other people is the quality of the final product of the creative process, it is based on a set of factors, internal and external aspects that should be considered in this process.

Bahia (2016), Piske \& Bahia (2012) point out that regarding gifted students, it is possible to notice creativity as an aspect that is inherent to their personality. Gifted students are different from their classmates. They have a significant need to develop their creative capacity. Most times, gifted students are not satisfied to learn what they already know, they are not accommodated and they do not like to reproduce what is taught at school. They like to learn about new topics related to their area of interest. Thus, offer a teaching for a student who has an average capacity to learn is very different from teaching a student who has a high capacity. The challenge can be much higher.

For Gross (2016) gifted student has a different behavior from his/her colleagues of his/her group, besides having his/her fastest way of reasoning in certain areas of his/her interest, he/she requires a stimulating environment, otherwise he/she can become unmotivated.

His/her behavior is productive, constructive and innovative, in this sense, he/she needs new challenges to incite his/her curiosity and also he/she needs to be motivated to learn more. His/her creativity excels during classes and he/she is always looking for new discoveries to his/her experiments and researches about different topics of knowledge. This way, create something means an important discovery for those who carried out an activity, because creativity involves unique 
feelings and it manifests itself by the imagination, feelings and emotions.

Flanders (2004) points out that creativity requires the mastery of a set of tools learned through culture. It is the use of these tools in exploration of new meaning that makes their application creative. "The creative individual also has to make use of the generative aspect of that language. Though the creative products differ, the creative process is the same" (Flanders, 2004: p. 101). Emotional experience appears crucial for creative exploration (Flanders, 2004).

According to Flanders (2004) creativity has a predominantly romantic aspect. From the romantic perspective, beauty, goodness, and truth are inherent in human nature and we have access this natural way of being through our emotions. "Romanticism offers a theory of the creative process: it is the personal exploration and authentic expression of the emotions" (Flanders, 2004: p. 95).

By the time, the individual is motivated to express his/her feelings through the realization of activities and tasks. He/she becomes more confident and satisfied about what he/she does. This can happen in the expression of a work of art, in a painting, sculpture, musical composition or in the simplest manifestation of creation.

The incentive to create, invent, innovate, can be decisive for the person who makes some activity, if he/she is motivated during the process of learning, he/she can feel able to produce and perform his/her best creations.

\section{Understanding of Vygotsky about Creativity}

Vygotsky understands creativity as an attribute that exists in all subjects, including the gifted. In the case of gifted, the author cites the importance of having different methodological procedures to develop their abilities (Vygotsky, 2010). For Vygotsky creativity can be crafted in artistic activities such as painting, drawing, theater, among others.

Both imagination and creativity are important aspects to the performance of each individual in the various areas of knowledge. Vygotsky $(1994,1996)$ understands these aspects as part of the higher psychological functions and inherent to human being. "Vygotsky understands imagination and creativity as being intrinsically related to the development of the superior psychological functions proper to mankind" (Stoltz et al., 2015: p. 66).

According to Vygotsky (2010) creativity is the most important activity because it is the expression of consciousness, thought and language. This aspect of creativity, as a factor inherent to the human condition must be understood in its socio-historical dimension. Stoltz et al. (2015) express:

Creativity is inherent to the human condition, and it is the most important activity because it is the expression of consciousness, thought and language. This aspect of creativity as an inherent factor of the human condition needs to be understood in its socio-historical dimension. In other words, from Vygotsky's point of view all psychic activity occurs in the mediation with the social history of human beings. It is this mediation that contributes to aspects such as creativity, subjectivity and the psychic world itself being 
immanent and inherent to that which is human, revealing all its historical and social potentiality. (Stoltz et al., 2015: p. 67).

It is possible to affirm that for Vygosky the process of creation is very important, because only from creativity can exist discoveries, various inventions, many creations, achievements of historical works, and also the transformation of reality. Human capacity is not limited to a simple reproduction.

According to Camargo (1997) the process of learning is not only a reproductive activity. What is "new" should be integrated with the previous content learned, that only happens with the active participation of the student, learning also involves a creative activity. "Every activity-Vygotsky said-not merely reproduce facts or vivid impressions, but create new images, new actions, belongs to this second creative or combinatorial function". (Vygotsky, 1990: p. 9).

Human beings have an unlimited capacity in the creation process and they should not be limited to activities that only reproduce what other individuals do or have already done. Vygotsky (1995) points out:

If human activity would be limited to reproduce the past, man would be a creature totally focused on the past, only capable of adjusting to the future if this was a reproduction of the past. Creative activity is thus what makes man a creature focused on the future, capable of shaping it and changing his current situation. (Vygotsky, 1995: p. 13).

The social environment can be decisive for the development of creativity. It will depend on how occur interpersonal relationships among individuals for the creation process occurs effectively. If we think that creativity is related to innovation, there will be no possibility to work creatively if individuals involved during the teaching-learning process only reproduce what is being discussed and done in class.

Innovation means creating opportunities of findings in relation to the areas of knowledge in an environment conducive to achieving a creative work. To have an effective work with creativity and innovation during the process of learning is necessary that teacher intervenes in the Zone of Proximal Development (ZPD) of their students.

Vygotsky $(2001,2008,2009,2010)$ affirms that a child follows an adult's example and gradually develops the ability to do certain tasks without help or assistance. Vygotsky explains the definition of zone of proximal development as the distance between the actual developmental level as determined by independent problem solving and the level of potential development as determined through problem solving under adult guidance, or in collaboration with more capable peers. Piske (2013) states that in the case of gifted students, capacity to solve individual problems may be higher compared to other students in their group. Stoltz \& Piske (2012) also point out that the ZPD may be defined as the distance between the actual level (capacity to solve individual problems) and the potential level (joint ability to solve problems, counting on help of experts). But it would not be possible to advance in learning if there is no work that involves 
creativity.

Creativity is a fundamental aspect to exist a responsive environment to develop the high abilities of gifted students. The school context where these students are inserted can be decisive for the development of their potential and talents. For Piske, Stoltz \& Camargo (2016) the manifestation of high abilities/giftedness exists only if there is an environment where the participation of individuals is effective and there is possibility to create new meanings and new products emerge, generating an environment where multiple relationships and experiences occur during the process of learning.

\section{Creativity at School}

The work with creativity in the school context is still not satisfactory, in general, there is no determination on the part of the teaching staff to establish goals about how to teach, about how to instigate creativity, and the objectives regarding the creative teaching are not clear, then It will hardly be possible to have a good result in relation to the work of teachers. It is elucidated that "enrichment programs are good educational alternatives that aim at further development of abilities and interests of gifted students" (Brasil, 1999).

Kane (2016) explains that it is fundamental exist contents according to the interest of students and incite their investigative spirit during the learning process. Therefore, it is essential to work with challenging activities to develop the creativity of students, as well as create opportunities for suggestions and contributions of the students at the beginning and during the teaching-learning process.

By analyzing the importance of the curriculum model, we find that the important thing is not to develop techniques to the curriculum, but develop concepts that permit to understand what it can provide to the students (Piske \& $\mathrm{Ba}$ hia, 2012). According to Piske (2016), it is important that teacher of gifted students knows how to instigate creativity of his/her students, providing an interesting teaching with creative exercises. Creativity is present in imagination and in creative potential of students, so it is important to work with provoking questions, because from a question to stimulate the curiosity of these students can exist the incentive to great discoveries. On fact, as Guérios (2002, 2005) identified in her research, prescriptive curricular models, knowledge broken up and absence of one epistemological perspective of the professor training that considers the relationship between students and knowledge, it results in reproductive professors without potential creative in its practical classes, compromising the development of the creative potential of the students. About of this, Guérios \& Sausen (2013: p. 300) written: "if they have internalized reproduction and memorization as a principle, these will become the basis of their educational actions and the teacher will have a student resulting from this posture". On the other hand, the development of a creative education can be understood from Stoltz and Weger (2015) as a thinking experienced in education, which effectively integrates the feeling, wanting and thinking.

Piske \& Bahia (2012) explain that motivation, creativity, involvement in the 
learning process will depend on the stimulation and training of the teaching staff in the classroom, because the educational practices can be decisive to make students demonstrate their interest about the content that is taught at school. When content is only taught by a transmission, there are no innovations, and this causes the lack of motivation to learn.

Piske \& Bahia (2012) point out that to instigate the creativity of gifted students there must be planning, goals and objectives for activities that represent new challenges for these students. It is necessary to exist dynamic classes and continuous attendance for gifted students, they need a innovate teaching and make new discoveries and they should not reproduce the same activities during classes.

In this sense, the mediation of the teacher is essential to intervene in the Zone of Proximal Development (ZPD) of gifted students to develop their potential and talents. But instead of offering an interesting teaching to their gifted students, some teachers inhibit their creativity during classes with a repetitive and standardized education.

Teachers can be good mediators of the process of teaching and learning if they are more attentive and have a sensitive look at the specifics of their students.

Piske $(2013,2016)$ give some recommendations for teachers to be good mediators during their classes, as follows:

$\checkmark$ Be a good observer to identify the needs of your students during all classes;

$\checkmark$ Work with activities that provoke the curiosity of students;

$\checkmark$ Oportunize students freedom to make questions in class;

$\checkmark$ Pay attention to the area of interest of students;

$\checkmark$ Perform artistic activities;

$\checkmark$ Allow students some moments to have freedom to express and choose what they want to learn, among other recommendations.

\section{Conclusion}

In conclusion, the mediation of teachers makes a difference in gifted education. As Vygotsky $(1993,2001,2009)$ explains, it is precisely through the mediation that is possible to develop the creative potential. In this sense, the training of the teaching staff reflects in how the mediation will take place during the process of teaching and learning. Therefore, it is essential that teachers are prepared to create a stimulating environment of potential and talents, as well as in performing a work with creativity of their students.

\section{References}

Alencar, E. M. L. S. (1995). Criatividade. Brasília: Editora Universidade de Brasília.

Alencar, E. M. L. S. (2001). Criatividade e educação de superdotados. Petrópolis, RJ: Vozes.

Alencar, E. M. L. S. de. (2014). Ajustamento Emocional e Social do Superdotado: Fatores Correlatos. In F. H. R. Piske, J. M. Machado, S. Bahia, \& T. Stoltz. (orgs.), Altas habilidades/Superdotação (AH/SD): Criatividade e emoção. [Giftedness: Creativity and 
Emotion] (pp. 149-162). Curitiba, Juruá.

Bahia, S. (2016). Criatividade na avaliação e intervenção na sobredotação. In F. H. R. Piske, T. Stoltz, J. M. Machado, \& S. Bahia. (orgs.), Altas habilidades/Superdotação (AH/SD) e Criatividade: Identificação e Atendimento. [Giftedness and Creativity: Identification and Specialized service] (pp. 145-164). Curitiba: Juruá.

Brasil (1999). Ministério da Educação. Secretaria de Educação Especial. Programa de capacitação de recursos humanos do ensino fundamental: Superdotação e talento. Brasília: MEC/SEESP. 2 v.

Camargo, D. de. (1997). As emoções no processo de aprendizagem. Tese (Doutorado em Educação), São Paulo: Pontifícia Universidade Católica de São Paulo. 199 páginas.

Cerna, M. Á. C. (1999). Aspectos importantes de la creatividad para trabajar en el aula. Educar Revista de Educación, 10, 10-18.

Esparza, J., Ruiz, M. J., Bermejo R., Ferrando M., \& Sainz M. (2016). Diseño de un programa para favorecer habilidades y estrategias del pensamiento científico-creativo. In F. H. R. Piske, T. Stoltz, J. M. Machado, \& S. Bahia. (orgs.), Altas habilidades/ Superdotação (AH/SD) e Criatividade: Identificação e Atendimento. [Giftedness and Creativity: Identification and Specialized service] (pp. 39-60). Curitiba: Juruá.

Flanders, J. L. (2004). Creativity and Emotion: Reformulating the Romantic Theory of Art. In B. Hardy-Vallée (Ed.), Cognitio: Matter and Mind. (pp. 95-102). Montreal: Université du Québec à Montreal.

Guérios, E. (2002). Espaços oficiais e intersticiais da formação docente: histórias de um grupo de professores na área de Ciências e Matemática. Tese (Doutorado em Educação). Campinas: Faculdade de Educação, Universidade Estadual de Campinas.

Guérios, E. (2005). Espaços intersticiais na formação docente: Indicativos para a formação continuada de professores que ensinam matemática. Cultura, formação e desenvolvimento profissional de professores que ensinam matemática (pp. 128-151). São Paulo: Musa.

Guérios, E., \& Sausen, S. (2013). Virtual Environment and Teaching Methodology in Higher Education in On-Site Modality. Diálogo Educacional, 13, 305-324.

Goldberg, C. (1986). The Interpersonal Aim of Creative Endeavor. The Journal of Creative Behavior, 20, 35-48. https://doi.org/10.1002/j.2162-6057.1986.tb00415.x

Gross, M. U. M. (2016). Developing Programs for Gifted and Talented Students. In F. H. R. Piske, T. Stoltz, J. M. Machado, \& S. Bahia (Eds.), Altas habilidades/Superdotação (AH/SD) e Criatividade: Identificação e Atendimento [Giftedness and Creativity: Identification and Specialized Service] (pp. 61-76). Curitiba: Juruá.

Kane, M. (2016). Gifted Learning Communities: Effective Teachers at Work. In F. H. R. Piske, T. Stoltz, J. M. Machado, \& S. Bahia (Eds.), Altas habilidades/Superdotação (AH/SD) e Criatividade: Identificação e Atendimento [Giftedness and Creativity: Identification and Specialized Service] (pp. 77-93). Curitiba: Juruá.

Lowenfeld, V., \& Brittain, W. L. (1977). Desenvolvimento da capacidade criadora. São Paulo: Mestre Jou.

Mindal C. B., \& Guérios, E. (2013) Formação de professores em instituições públicas de ensino superior no Brasil: Diversidade de problemas, impasses, dilemas e pontos de tensão. Educar em Revista, No. 50, 21-33.

https://doi.org/10.1590/S0104-40602013000400003

Pfeiffer, S. (2016). Leading Edge Perspectives on Gifted Assessment. In F. H. R. Piske, T. Stoltz, J. M. Machado, \& S. Bahia (Eds.), Altas habilidades/Superdotação (AH/SD) e Criatividade: Identificação e Atendimento [Giftedness and Creativity: Identification and Specialized Service] (pp. 95-122). Curitiba: Juruá. 
Piske, F. H. R. (2013). O desenvolvimento socioemocional de alunos com altas habilidades/ superdotação (AH/SD) no contexto escolar: Contribuiçôes a partir de Vygotsky. Dissertação (Mestrado em Educação), Curitiba: Universidade Federal do Paraná, 166 páginas.

Piske, F. H. R. (2015). Aluno (a) com altas habilidades/superdotação (AH/SD): Quem é essa criança? In V Seminário Internacional de Educação de Pinhais (pp. 1-15).

Piske, F. H. R. (2016). Alunos com Altas Habilidades/Superdotação (AH/SD): Como identificá-los? In F. H. R. Piske, T. Stoltz, J. M. Machado, \& S. Bahia (Eds.), Altas habilidades/Superdotação (AH/SD) e Criatividade: Identificação e Atendimento [Giftedness and Creativity: Identification and Specialized Service] (pp. 249-259). Curitiba: Juruá.

Piske, F. H. R., \& Bahia, S. (2012). Criatividade e Inovação: A Importância de uma boa formação docente para desenvolver as Altas Habilidades. In Actas do I Seminário Internacional "Contributos da Psicologia em Contextos Educativos" (pp. 79-86). Braga: Universidade do Minho.

Piske, F. H. R., Falcade, I., Stoltz, T., \& Asinelli-Luz, A. (2015). Os direitos humanos de alunos superdotados: A necessidade do atendimento educacional especializado. In E. Guérios, \& T. Stoltz (Eds.), Educação em direitos humanos: Qual o sentido (Vol. 1, pp. 203-224)? Ijuí: Unijuí.

Piske, F. H. R., \& Stoltz, T. (2013). Criatividade na escola: A necessidade de reavaliar as práticas educacionais aos alunos superdotados. In F. H. R. Piske, \& S. Bahia (Eds.), Criatividade na escola: $O$ desenvolvimento de potencialidades, altas habilidades $e$ talentos [Creativity at School: Development of Potentials, High Abilities and Talents] (pp. 141-158). Curitiba, Juruá.

Piske, F. H. R., Stoltz T., \& Camargo, D. (2016). A compreensão de Vigotski sobre a criança com altas habilidades/superdotação, genialidade e talento. In F. H. R. Piske, T. Stoltz, J. M. Machado, \& S. Bahia (Eds.), Altas habilidades/Superdotação (AH/SD) e Criatividade: Identificação e Atendimento [Giftedness and Creativity: Identification and Specialized Service] (pp. 207-217). Curitiba: Juruá.

Piske, F. H. R., Stoltz, T., \& Machado, J. M. (2014). Creative Education for Gifted Children. Creative Education, 5, 347-352. http://www.scirp.org/journal/PaperInformation.aspx?PaperID=45206

Piske, F. H. R., Stoltz, T., Machado, J. M., Vestena, C. L. B., Oliveira, C. S., Freitas, S. P., \& Machado, C. L. (2016). Working with Creativity of Gifted Students through Ludic Teaching. Creative Education, 7, 1641-1647. http://file.scirp.org/pdf/CE_2016072718141930.pdf

Renzulli, J. S. (2005). The Three-Ring Conception of Giftedness: A Developmental Model for Creative Productivity. In R. Sternberg, \& J. Davidson (Eds.), Conception of Giftedness. Cambridge: University of Cambridge. https://doi.org/10.1017/CBO9780511610455.015

Renzulli, J. S., \& Reis, S. M. (1997). The Schoolwide Enrichment Model (2nd ed.). Mansfield Center, CT: Creative Learning Press.

Stoltz, T. (2016). Imaginação e criatividade na educação: a necessidade de outro olhar. In F. H. R. Piske, T. Stoltz, J. M. Machado, \& S. Bahia (Eds.), Altas habilidades/ Superdotação (AH/SD) e Criatividade: Identificação e Atendimento [Giftedness and Creativity: Identification and Specialized Service] (pp. 191-206). Curitiba: Juruá.

Stoltz, T., \& Piske, F. H. R. (2012). Vygotsky e a questão do talento e da genialidade. In L. C. Moreira, \& T. Stoltz (Eds.), Altas habilidades/superdotação, talento, dotação e educação [Giftedness, Talent and Education] (pp. 251-259). Curitiba: Juruá.

Stoltz, T., Piske, F. H. R., Freitas, M. F. Q., D’Aroz, M. S., \& Machado, J. M. (2015). Creativity in Gifted Education: Contributions from Vygotsky and Piaget. Creative Educa- 
tion, 6, 64-70. http://file.scirp.org/pdf/CE_2015011416262533.pdf https://doi.org/10.4236/ce.2015.61005

Stoltz, T., \& Weger, U. (2015). O pensar vivenciado na formação de professores. Educar em Revista, No. 56, 67-83. https://doi.org/10.1590/0104-4060.41444

Virgolim, A. M. R., Fleith, D. S., \& Pereira, M. S. N. (2009). Toc, Toc, plim, plim: Lidando com as emoções, brincando com o pensamento através da criatividade. Campinas, SP: Papirus.

Vygotsky, L. S. (1990). La imaginación y el arte en la infancia. Madrid: Ediciones Akal.

Vygotsky, L. S. (1993). Obras Escogidas. Vol. II. Madrid: Ministério Educacción y Ciência, Visor.

Vygotsky, L. S. (1994). Imagination and Creativity of the Adolescent. In R. van Der Veer, \& J. Valsiner (Eds.), The Vygotsky Reader. Hoboken, NJ: Blackwell.

Vygotsky, L. S. (1995). Fantasi och kreativitet $i$ barndomen [Imagination and Creativity in Childhood]. Göteborg: Daidalos.

Vygotsky, L. S. (1996). Obras Escogidas (Vol. 4). Psicología Infantil, Madrid: Visor.

Vygotsky, L. S. (2001). Psicologia da arte. São Paulo: Martins Fontes.

Vygotsky, L. S. (2008). A Formação Social da Mente. São Paulo: Martins Fontes.

Vygotsky, L. S. (2009). Imaginação e criação na infância: Ensaio psicológico: Livro para professores. São Paulo: Ática.

Vygotsky, L. S. (2010). Psicologia Pedagógica. São Paulo: Martins Fontes.

Scientific Research Publishing

Submit or recommend next manuscript to SCIRP and we will provide best service for you:

Accepting pre-submission inquiries through Email, Facebook, LinkedIn, Twitter, etc. A wide selection of journals (inclusive of 9 subjects, more than 200 journals)

Providing 24-hour high-quality service

User-friendly online submission system

Fair and swift peer-review system

Efficient typesetting and proofreading procedure

Display of the result of downloads and visits, as well as the number of cited articles

Maximum dissemination of your research work

Submit your manuscript at: http://papersubmission.scirp.org/

Or contact ce@scirp.org 